\title{
HOLOCENE LAKE SEDIMENTS AS A SOURCE OF BUILDING MATERIAL IN ANCIENT EGYPT; ARCHEOMETRIC EVIDENCE FROM WADI TUMILAT (NILE DELTA)
}

\author{
Małgorzata Zaremba $^{1^{*}}$, Jerzy Trzciński ${ }^{2}$, Fabian Welc ${ }^{1}$ \\ ${ }^{1}$ Institute of Archaeology, Cardinal Stefan Wyszynski University, Warsaw, Poland, e-mail: m.zaremba@student.uksw.edu.pl; \\ f.welc@uksw.edu.pl \\ 2 Wrocław Research Centre EIT+,Wroctaw, Poland, e-mail: jerzy.trzcinski59@gmail.com \\ * corresponding author
}

\begin{abstract}
The Tell el-Retaba archaeological site is located in the middle part of Wadi Tumilat, which extends along the north-eastern margin of the Nile Delta. It contains fragments of fortified and domestic objects of the ancient fortress and other constructions built of mud bricks. The establishment and functioning of the fortress is dated at the times of the reign of two great pharaohs, Ramesses II and Ramesses III ( $13^{\text {th }}$ and $12^{\text {th }}$ centuries BC). The grain size composition of the sediments used for mud brick production had significant influence on their physical and mechanical properties, which was used by the ancient Egyptians for the improvement of bricks. The finest fractions, clay and silt, which generally comprise clay minerals and organic matter played a significant role. These components significantly influenced the mud brick properties and resulted in a structural cohesion of the material. The second important component of mud bricks were coarse fractions - sand and gravel. The source of material used for brick production were the natural sediments located in the vicinity of the fortress, i.e. the Holocene lake clay and the Pleistocene gravel and sand of the gezira formation, deposited by a braided river. Clay sediments have a variable lithology as can be deduced from grain size composition of mud bricks and their properties. This variability was caused by a variable regime of the Nile, which supplied material to the lake basin. Geological studies were used to recognize ancient environment and morphology of the area, and to find clay, sand and gravel open-pits that existed in the area. The fortress site was selected optimally in relation to the landscape morphology and close vicinity of the source of basic material and water used for mud brick production. The area around the fortress was substantially transformed by humans due to settlement.
\end{abstract}

Key words: clay-silt-sand-gravel, mud bricks, fortress walls, open-pit mine, climate changes

Manuscript received 2 June 2017, accepted 1 December 2017

\section{INTRODUCTION}

Beside a stone, sun-dried mud bricks were the basic construction material in ancient Egypt (Spencer, 1979; Kemp, 2009; Emery, 2011). Their common use in this area resulted from easy access to a source material used for their production. Basically, bricks were made from river muds commonly available in the Nile Valley and Delta. These sediments, beside coarse grains, are rich in fine fractions, i.e. silt and clay, which after drying resulted in cohesion of the material. Due to their grain size composition, muds were a ready, natural mixture for mud brick production. If the mud was too dense that is contained too much clay, sediments with coarse fractions (sand and gravel) were added to the mixture. The mixture was additionally supple- mented with plant fragments, i.e. hay or straw to enhance cohesiveness of a mud brick as a whole, which must have additionally increased its durability.

Tell el-Retaba is the archaeological site, in which remains of ancient structures having various functions and constructed of mud bricks were found (Rzepka et al., 2011; Rzepka et al., 2012/2013; Rzepka et al., 2014; Rzepka et al., 2015). The objects are dated at the times of reigns of two great pharaohs, Ramesses II and Ramesses III (Petrie and Duncan, 1906; Górka and Rzepka, 2011). The Tell el-Retaba site comprises ruins of very numerous and variable constructions exposed here during the activities of the Polish-Slovak Archaeological Mission since 2007 (Rzepka et al., 2009). The constructions mainly include remains of fortified structures, such as "Wall 1" - fortifi- 


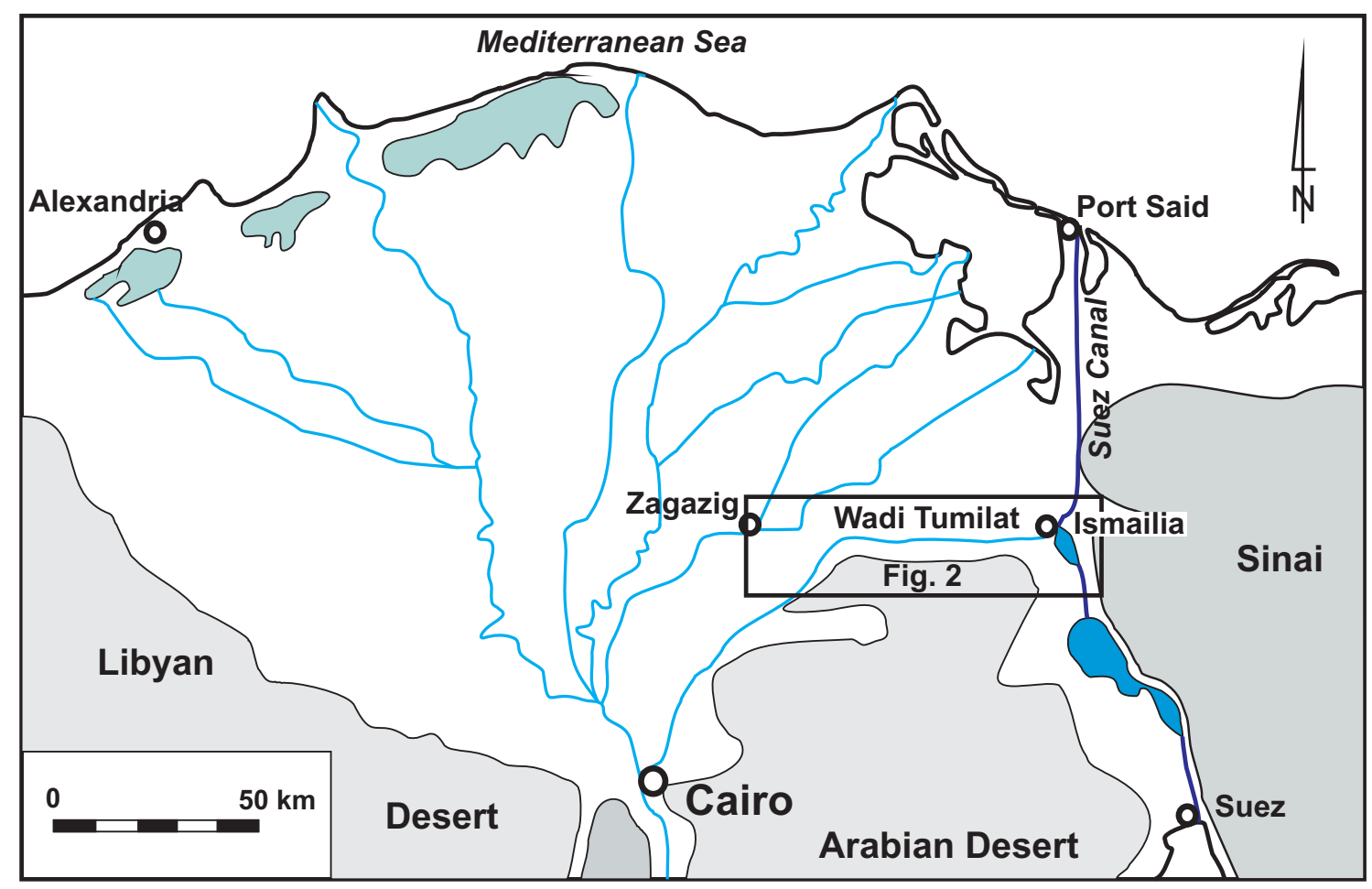

Fig. 1. Location of Wadi Tumilat in the Nile Delta.

cations from the $19^{\text {th }}$ dynasty ( $13^{\text {th }}$ century BC), "Wall 2 ", "Wall 3" and a migdol gate - fortifications from the $20^{\text {th }}$ dynasty $\left(12^{\text {th }}\right.$ century BC). Fragments of the exposures of these constructions have been presented by Trzciński et al. (2016). Remnants of domestic constructions, and other buildings and diverse constructions are also common in the site. Detailed studies of physical-mechanical properties, in particular a durability of mud bricks from fortified and domestic structures have been conducted by Zaremba (2017).

A poor preservation state of the mud brick architecture in Tell el-Retaba results from climate change that took place both during the fortress activity and after its abandonment. Increase of rainfall in more humid periods caused soaking of the constructions from the top and washing out of the bricks. Additionally, oscillations of groundwater level resulted in soaking of water from the bottom to the lowermost parts of the fortified walls. In such conditions both the basement and the mud bricks underwent softening, thus losing their bearing capacity and the entire construction became unstable (see Trzciński et al., 2016).

Due to the location of the Ramesses II and Ramesses III fortress in a wadi valley directly adjacent to the desert, the source of the mud for bricks could not have been a typical fluvial mud. A research conducted in Tell el-Retaba indicated that lake deposits occur in a direct vicinity of the site (Rzepka et al., 2015). In the Nile Delta, such deposits are often encountered in various geological settings. The age of these sediments is also variable. No age determinations have been done for lake sediments at Tell el-Retaba. However, their geological position with regard to the gezira sands indicates that they must have been formed in the Holocene.

\section{LOCATION}

The Tell el-Retaba archaeological site is located in the south-eastern part of the Nile Delta, $35 \mathrm{~km}$ from the city of Ismailia, in Wadi Tumilat (Fig. 1). This is a narrow, WEoriented valley, which is the extreme, south-easternmost part of the Nile Delta, about $52 \mathrm{~km}$ long and 2 to $9 \mathrm{~km}$ wide. Wadi Tumilat connects the mid-eastern part of the Nile Delta with the Suez Strait, and nowadays with the Suez Canal. The eastern boundary of the valley is marked by the city of Ismailia and the Timsah Lake and the western - by the El-Abbasa city to the east of Zagazig (Fig. 2).

\section{WADI TUMILAT: GEOMORPHOLOGY, CLIMATE AND HYDROLOGY}

Based on a variable morphology of the area, Wadi Tumilat was subdivided into three divisions: western, central and eastern (Redmount, 1989). The largest is the western division, which extends to the east along a distance of $24 \mathrm{~m}$ from the western mouth of the valley to a point known as Ras elWadi, in which the valley rapidly narrows (Fig. 3). Here, the width of the valley is from 2 to $6 \mathrm{~km}$. The division is characterized by a rather flat low ground, lying at 4 to $6 \mathrm{~m}$ a.s.l. It is built mainly of fluvial sediments deposited during the Nile floods. The northern part of the division lies at a higher ground that the remaining part and is a slope of the desert.

The central division is 4 to $5 \mathrm{~km}$ wide and extends at distance of about $13 \mathrm{~km}$ from Ras el-Wadi to the Abu Suweir village and to the locality of the Tell el-Maskhuta - Pithom 


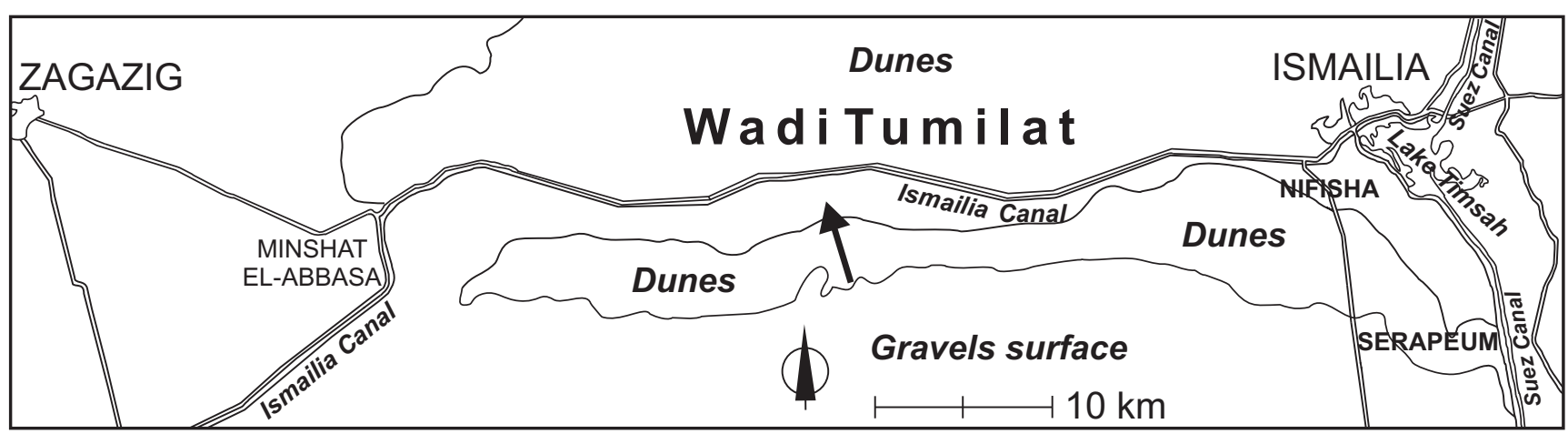

Fig. 2. Wadi Tumilat. Arrow indicates the Tell el-Retaba archaeological site

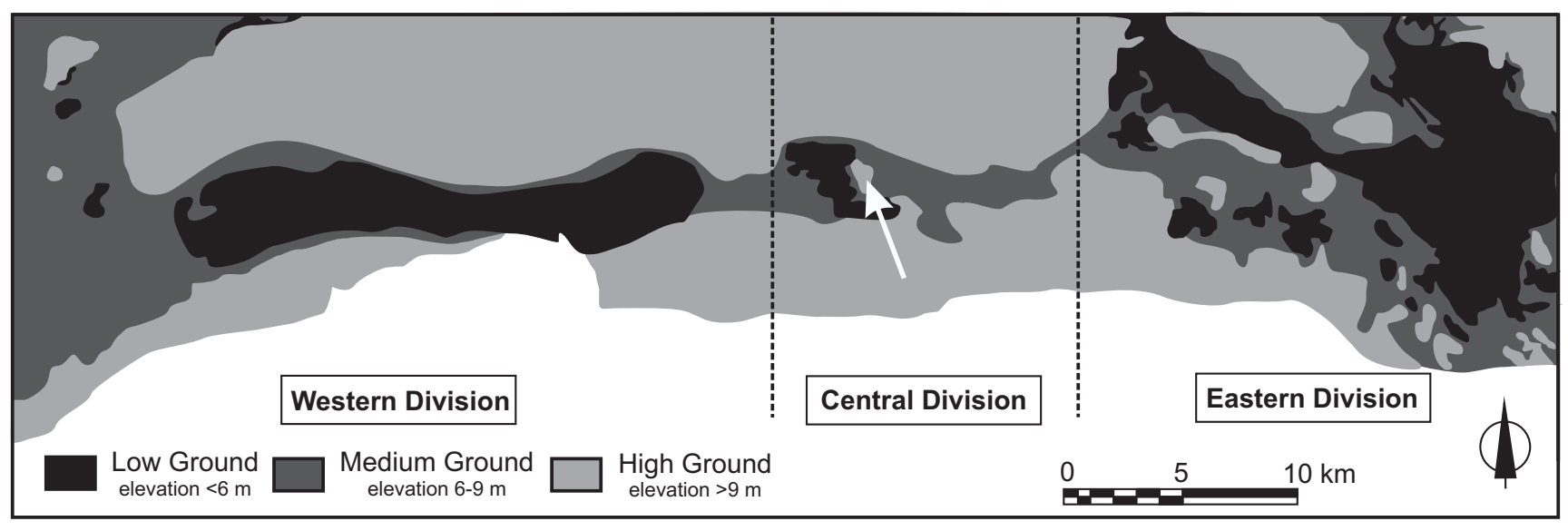

Fig. 3. The three divisions of Wadi Tumilat: Western, Central and Eastern (Redmount 1989, fig. 4, modified). Dashed lines indicates the boundaries between the divisions; arrow indicates the Tell el-Retaba archaeological site

archaeological site (Fig. 1). It differs from the western division both in topography and the sediments it is built of. Besides the sandy fluvial deposits, it is composed also of aeolian sand and fluvial gravel. Intense erosional processes resulted in a variable morphology of the area. The elevation is at 6 to $8 \mathrm{~m}$ a.s.l., i.e. slightly higher than in the western division. A characteristic feature of this division is a presence of vast, but rare depressions, in which islands occur. In times, when Wadi Tumilat was a course of the flooding Nile waters, lakes were formed in the depressions. A series of such lakes have been documented by maps from the mid$19^{\text {th }}$ and $20^{\text {th }}$ centuries. Similarly as in the western division, but along the southern margin of the central division, a belt of higher ground may be observed, on which dunes advance. In the belt of a high ground (10 $\mathrm{m}$ a.s.1.) a series of depressions occurs, interpreted as the ancient lakes. The elevation of the area suggests that none of the lakes in the area was very deep. Some of them are also filled with water at present. It is assumed that the lakes mark a southern margin of the non-existing extensive Mahsama Lake. A number of archaeological sites in the area suggest that numerous water reservoirs existed there in ancient times, around which settlements developed. Pollen analysis indicates that the area was rich in vegetation characteristic of regions that were periodically flooded and the discovered animal remains point to fresh water reservoirs (Redmount, 1989). The Tell el-Retaba archaeological site lies within this division (Fig. 2).

The eastern division, similarly as the central division, is characterized by variable morphology shaped during intense erosional processes. The surface of the area lies slightly above $10 \mathrm{~m}$ a.s.l. Near Tell el-Maskhuta, the valley widens to the north and reaches a width of $9 \mathrm{~km}$. The division becomes narrower towards the east. The eastern division is mainly a depression, which at present is partly occupied by the Timsah Lake. Previously the lake extended further to the west. Sporadic depressions that formed lagoons during large floods were located to the south from the western extent of the Timsah Lake near the Nefisha village (Fig. 2). Besides the sediments of the former lake and lagoons, this part of the valley is built of fluvial sand and gravel. The latter, near the Nefisha village is replaced by fine sand. Numerous dunes are also present close to the village.

Today Wadi Tumilat area is located in a temperate desert climate zone, which, similarly as in the Nile Delta, did not change significantly over a long time span. Only in the late Pre-dynastic period and in the beginning of the $1^{\text {st }} \mathrm{dy}$ nasty (3,200-2,700 years BC) the climate was more humid. It is assumed that in ancient times the climate was similar as today (Redmount, 1989). 


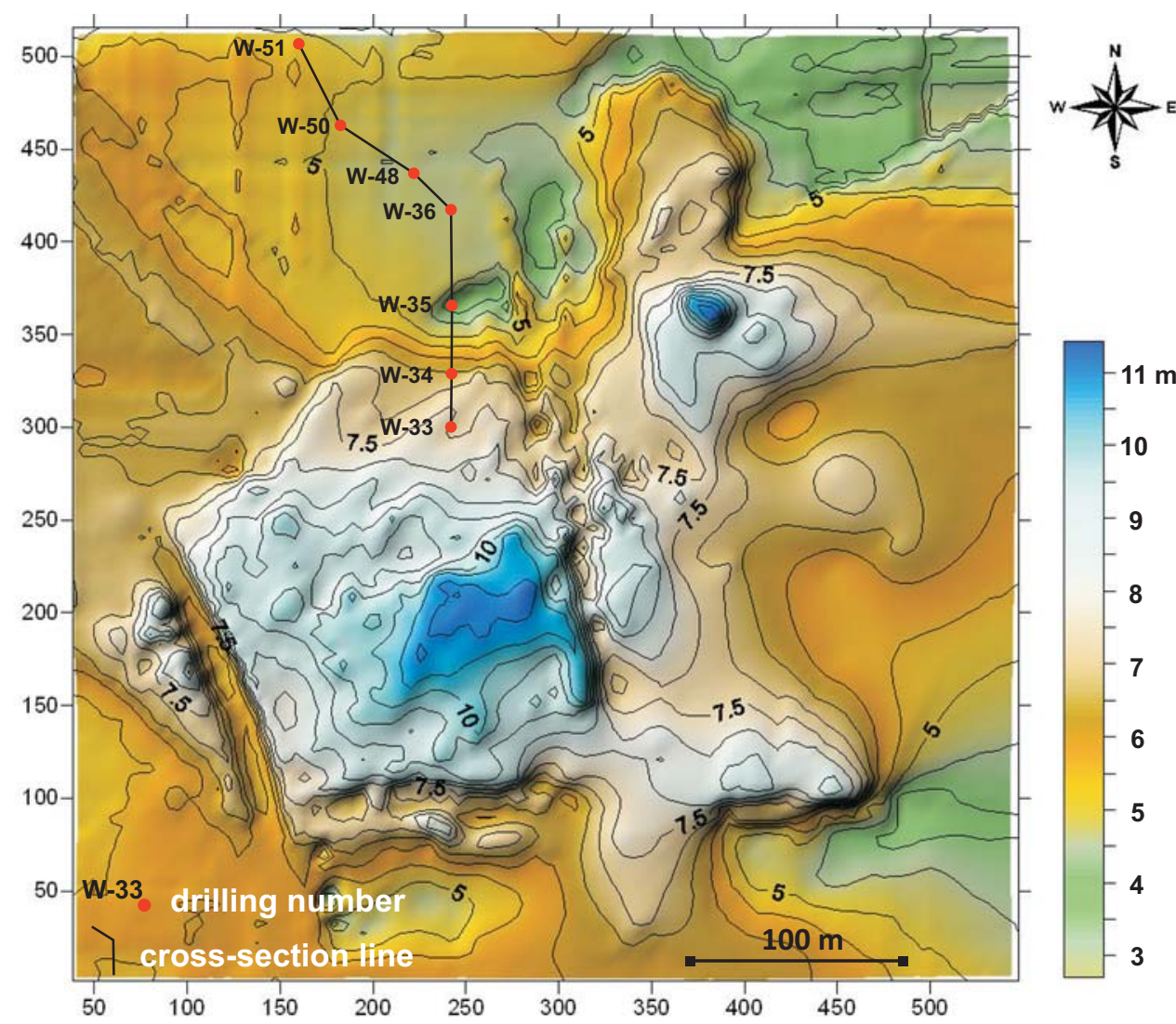

Fig. 4. Topographic map of the Tell el-Retaba archaeological site with location of drillings and cross-section line (map from report of the Polish-Slovak Archaeological Mission, season 2007).

Water in Wadi Tumilat came from 3 main sources: seasonal floods of the Nile, groundwater and lakes. Its quantity in the region depended most significantly on the Nile floods. The location, quality and level of the water in the lakes depended on the regularity with which the area was flooded by the Nile. It may be assumed that during normal floods, water reached Ras el-Wadi, whereas it extended further to the Timsah Lake only in extreme cases. Determining the range of floods in ancient times is very difficult. This range depended on many factors, i.e. the magnitude of the flood and the presence or lack of channels and embankments in the wadi and its vicinity. Studies of the sediments indicate that till 4,000 years BC the eastern part of Wadi Tumilat only was the alluvial plain of the Nile (Butzer, 1976).

Regions to the east of Ras el-Wadi were located above the groundwater level. Based on restricted and fragmentary data on the Nile floods, short-term oscillations of the groundwater level can be deduced. The groundwater level decreased during the Early Dynasties and in the Old Kingdom (c. 3150-2181 BC). In the First Intermediate Period and in the beginning of the Middle Kingdom (c. 2250-1950 BC) the Nile floods were catastrophically low. The situation reversed completely in the next century. In 1840-1779 BC a series of high floods took place. In $1200 \mathrm{BC}$, the water level was so low that the royal residence located along Pelusiak, the Nile tributary, had to be abandoned, and the ruler moved to a residence along another tributary - Tanitik. Very high water level in the Nile was reported in the $9^{\text {th }}, 7^{\text {th }}$ and $5^{\text {th }}$ centuries $\mathrm{BC}$ and the $1^{\text {st }}$ century AD (Butzer, 1976).

The only source for the Timsah Lake was a water from the Nile. Water reached the lake during high floods only. Lack of outflow from the lake resulted in water stagnation till it soaked in a ground or evaporated. Without influx of freshwater, the reservoir diminished, its salinity increased and numerous smaller reservoirs were formed within its area. At first, the water basin was located at 2 to $6 \mathrm{~m}$ a.s.l. It was much larger, more irregular and shallower than today (Redmount, 1989).

\section{METHODOLOGY OF RESEARCH}

Numerous drillings were made during field work, which enabled the interpretation of the geology of the area and indication of the extent of some sedimentary units (Rzepka et al., 2015). This documentation was used to prepare a paleogeographic reconstruction and to determine a range of lake sediments and anthropogenic transformations in the study area. Samples for laboratory tests and for the determination of physical and mechanical parameters were cut out from selected mud bricks collected from remains of the constructions exposed in the site (Trzciński et al., 2016). The analyses were conducted according to the Polish norms PN-88/B-04481 and PKN-CEN ISO/TS 17892-7. 
Fig. 5. Geological cross-section of the northern slope of the Tell el-Retaba archaeological site. A - present situation (Zaremba 2017), B - reconstruction during fortress construction, $\mathrm{C}-$ reconstruction prior to settlement. Explanations of symbols on cross-section A: 1 - medium sands $(0.1-0.5 \mathrm{~mm})$, light- to darkgrey in colour, alluvial origin, Pleistocene; 2 - clays, silty clays, sandy clays, ash-grey to blue in colour with fragments of plants, lake origin, Holocene; 3 - silty sands with single pebbles $(10-30 \mathrm{~mm})$, light- to darkgrey in colour, reaction with $\mathrm{HCl}$ medium or strong, diluvial-eolian origin, age of formation from fortress construction to its abandonment; 4 - well-sorted sands (0.1$0.3 \mathrm{~mm}$ ), ash-grey in colour, weak reaction with $\mathrm{HCl}$, eolian origin, age of formation after fortress construction; 5 - sandy loam, brown in colour, strong reaction with $\mathrm{HCl}$, diluvial origin (flow of material from the slope), age determination from the beginnings of fortress functioning to its abandonment; 6 - poorly sorted sands $(0.1-1 \mathrm{~mm})$, silty sands with clay interbeds, light-yellow through light-grey to dark-grey in colour, lack of reaction with $\mathrm{HCl}$, anthropogenic origin, formed in the end of fortress functioning to present-day; blue line - water level.

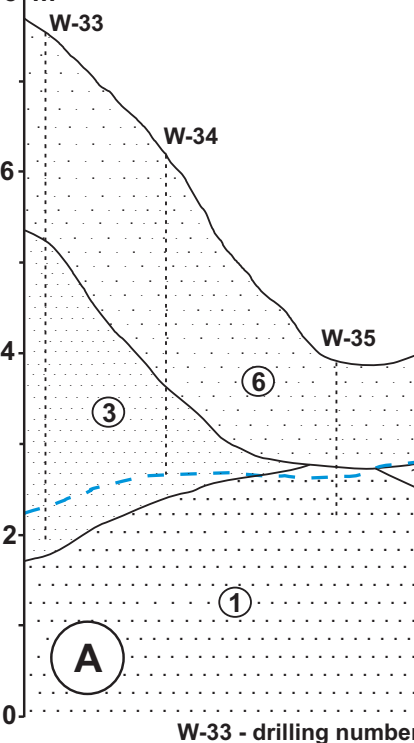

$\mathrm{s}$

${ }^{8}{ }^{\mathrm{m}}$

W-33 - drilling number

NW

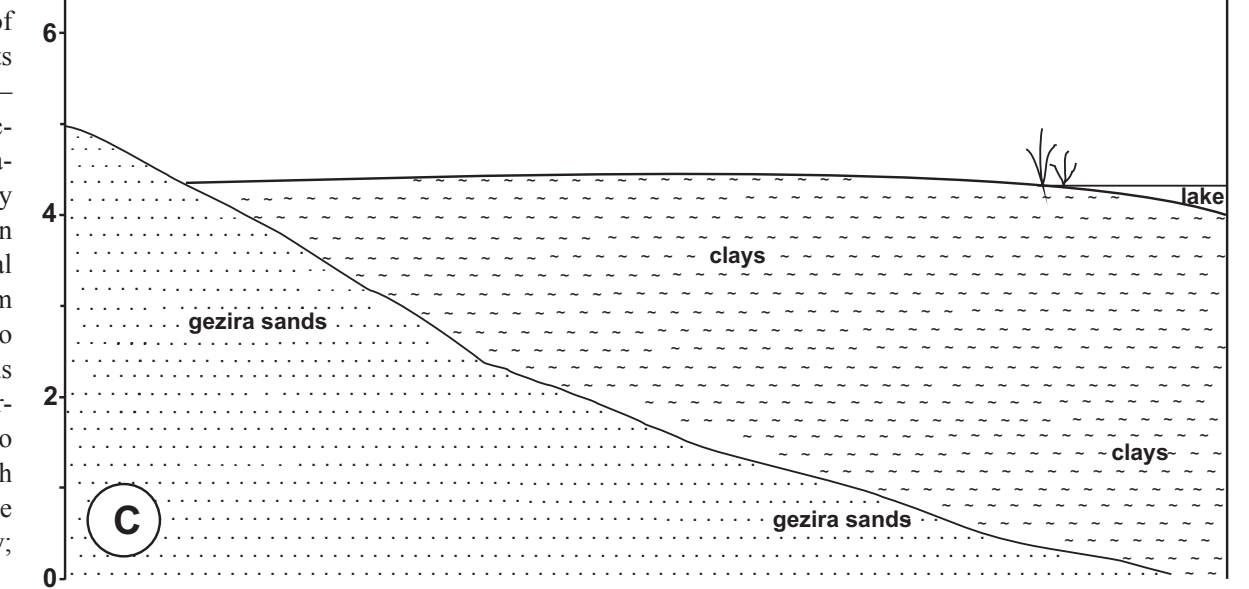




\section{GEOLOGICAL STRUCTURE AND HISTORY OF THE NORTHERN PART OF THE TELL EL RETABA ARCHAEOLOGICAL SITE}

Based on the conducted drillings, a geological cross-section was prepared, north-south oriented with a divergence to the NW, and cutting a northern slope of the site (Figs 4, 5), which is the lowermost part of the site (Zaremba, 2017). In this area presence and range of fine sediments - clay lying directly on gezira sand - was identified (Rzepka et al., 2015).

According to the cross-section, the gezira sand forms a distinct elevation and occur in a basement. Towards the north and northwest, a top of the sand bed descends. On the slope of the depression there is a lake clay. Its top forms a small north-south oriented slope with a height difference of $1.5 \mathrm{~m}$ and covered by sandy-clay sediments. The entire area is covered by silty sand and poorly sorted sand that form a cover of a varying thickness (from several centimetres to several metres). The groundwater level is at about $3 \mathrm{~m}$ (local level) and decreases towards the south, to stabilize at about $2 \mathrm{~m}$. Towards the north, the groundwater level runs through a silty sand, following a top of a gezira sand, and next locates on a top of a clay to disappear in sand-loam sediments.

The oldest sediments at the Tell el-Retaba archaeological site and its vicinity are very thick horizons of medium sand, light to dark grey in colour. It is slightly carbonate only and belong to a gezira sand (Figs 5A, 6A) formed in the Late Pleistocene as a result of the Nile accumulation, most probably by a high-energy braided river (Stanley and Warne, 1993; Welc and Marks, 2014; Welc, 2016). Almost along the entire cross-section, this sand is overlain by a thick clay - the lake sediments that were formed in the Holocene (Stanley and Warne 1993; Welc and Marks, 2014; Welc, 2016). Clay sediments occurring in the northern, marginal part of the ancient lake are ash-grey to blue in colour and contain a significant amount of dispersed organic matter and calcium carbonate. Numerous fragments of non-decomposed plant fragments also occur (Fig. 6B). Clay in the north-western part is dark grey and with sligh content of carbonates.

A clay-sand, brown coloured lens with a maximal thickness up to $50 \mathrm{~cm}$ extends on a distance of about $135 \mathrm{~m}$ towards the northeast. These sediments are characterized by strong reaction with $\mathrm{HCl}$, which, together with the colour indicate a large contribution of organic matter rich in calcium carbonate. This is deluvial sediment formed on the slope due to washing out by water of clay sediments mixed with sand. Above the clay-sand lens occurs a lens of well sorted sands, ash-grey in colour. Their grain size points to eolian origin. The slight admixture of calcium carbonate causes weak reaction with $\mathrm{HCl}$. The sands are part of an ancient sand dune formed on the slope after the fortress construction. In the southern part of the cross-section, above the gezira sands occurs a bed of light- to dark-grey coloured silty sands with a few pebbles. The sediments react with $\mathrm{HCl}$, indicating the presence of calcium carbonate. Darker coloured interbeds contain more dispersed $\mathrm{CaCO}_{3}$. Towards the north the thickness of this bed decreases, to disappear completely. The origin of these sediments is

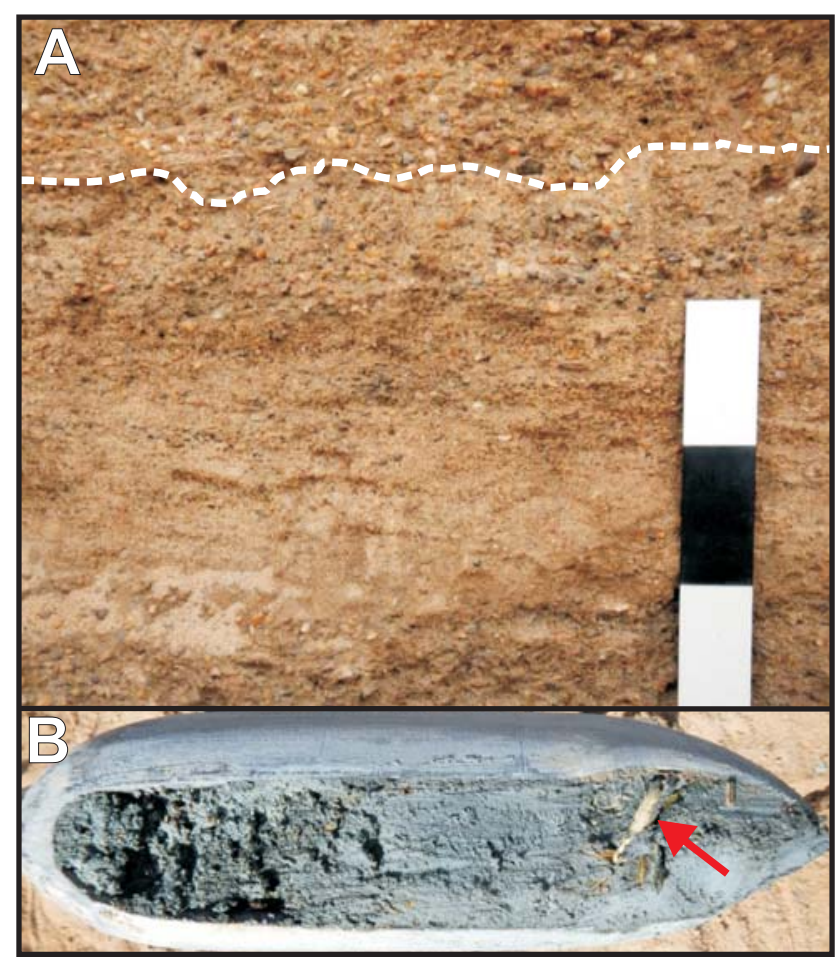

Fig. 6. Main substrate sediments in the Tell el-Retaba archaeological site: A - alluvial sands of the gezira formation, overlain by gravels (above the dashed line), B - ash-grey lake clays with fragments of plant remains (marked with arrow), length of auger $20 \mathrm{~cm}$

probably mixed, diluvial-eolian. The age of these sediments is assumed as the interval between the establishment of the fortress to its abandonment (Fig. 5A).

The surface of the area is covered by a continuous, $2 \mathrm{~m}$ thick layer of sediments. To the northeast where clays occur, the thickness diminishes to about a dozen centimetres. The sediment is dominated by poorly sorted sands with single pebbles and ceramic fragments. Interbeds of gravel and silt are also present. The colour of sands with gravel is from light yellow through light pink to dark grey and do not contain calcium carbonate. This layer is composed of material from the fortress, formed during its destruction under the influence of various factors: wind, rain water and mankind. The layer was formed from the end of the fortress functioning till present.

\section{INFLUENCE OF GRAIN SIZE COMPOSITION ON THE PHYSICAL AND MECHANICAL PROPERTIES OF THE MUD BRICKS}

The contribution of the sand fraction in mud bricks from all fortified objects varies between $68 \%$ and $88 \%$, and most commonly is at about $75-80 \%$ (Fig. 7). A deviation from these values is observed in the case of "Wall 2" - W2 (88\%) and foundation of "Wall 2" - W2 F (68\%). An identical grain size composition of the grey-brown mud bricks from the $\log (\mathrm{W} 1 \mathrm{C})$ and of the green mud bricks from the internal extension (W1 IE) of "Wall 1" suggests 


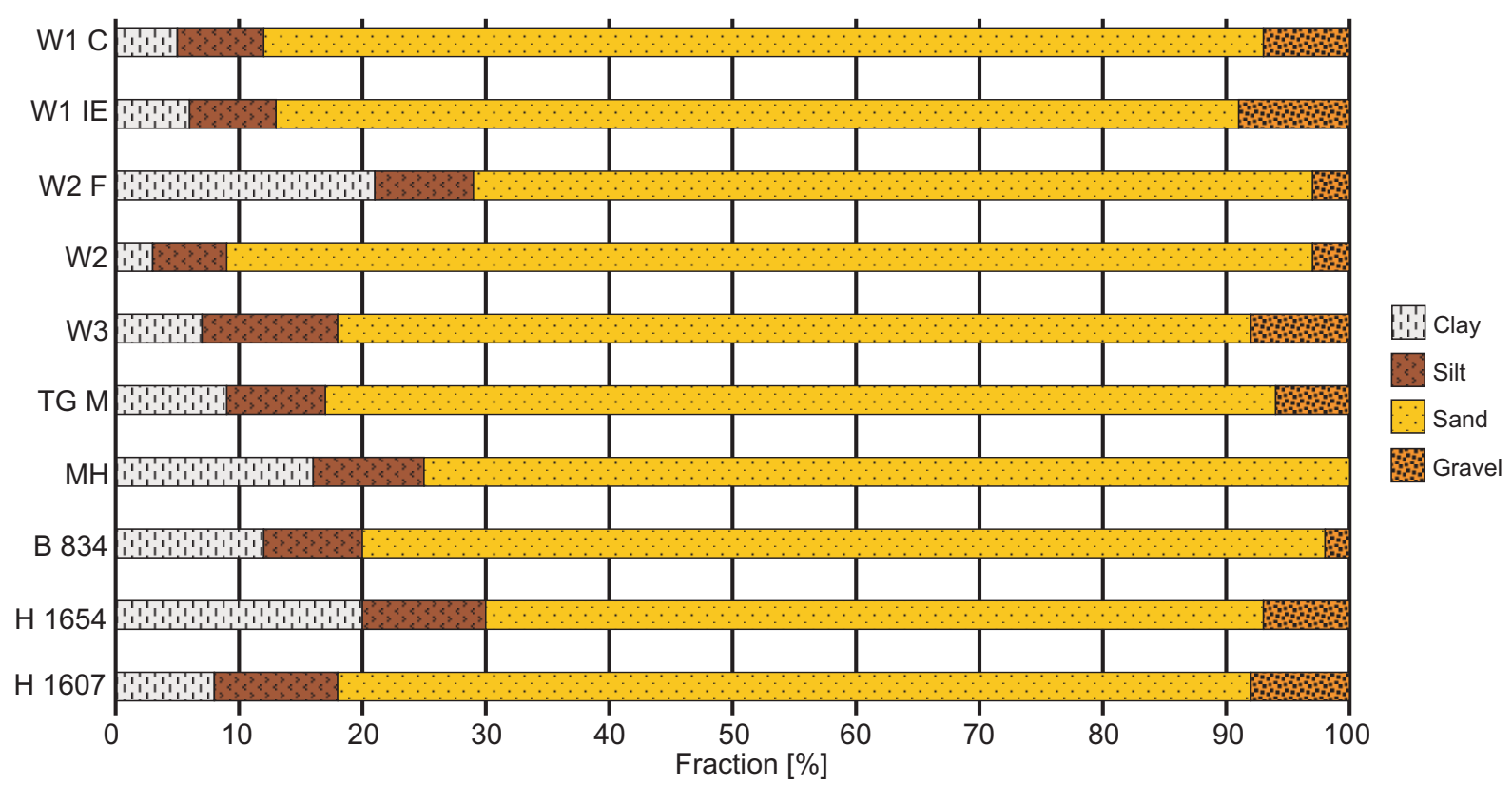

Fig. 7. Grain size composition of the mud bricks from fortified and domestic objects of the Tell el-Retaba archaeological site (Zaremba 2017). Symbols of objects according to Table 1

that the material for their production had the same source. Differences in the range of $1-3 \%$ in the content of the gravel, sand and clay fraction may be caused by variable proportions or a diverse lithology used for the mixture of sediments. The material for mud brick production probably had its source in close vicinity of the fortress. Most probably there were 3 types of sediments from the vicinity of the fortress: gravels and sands of the gezira formation and the silty-clay lake sediments (Rzepka et al., 2015; Trzciński et al., 2016). The bricks were produced on site, from local material, for the requirements of the fortress that is on the order of the rulers that had financed its construction, and the local community working and living there.
The contribution of the silt fraction in mud bricks from all objects is similar and varies within 6-8\% (Fig. 7). Slightly higher contents of this fraction were noted in mud bricks from "Wall 3" W3 (11\%). The largest contribution of the silt fraction must have come from lake sediments. Its small amounts could also be found in sands and gravels. Apart from the conducted drillings, no other deep logs of lake sediments are known from the area. It can be assumed that the material transported along the Nile tributary flowing through Wadi Tumilat supplied more silt fraction at high water and more clay fraction at low water. Cyclic changes in the regime of alluvial transportation must have caused the formation of interbedded, silt-clay lake sedi-

Table 1

Properties of mud bricks from the Tell el-Retaba archaeological site. Symbols of objects from which mud bricks were collected for analyses: W1 C - core of "Wall 1", W1 IE - internal extension of "Wall 1", W2 F - foundation of "Wall 2", W3 _ "Wall 3", TG M - migdol entrance gate, MH - Mustafa's House, B 834 - Building No. 834, H 1654 - House No. 1654, H 1607 - House No. 1607.

\begin{tabular}{|c|c|c|c|c|c|c|c|c|}
\hline & & & & Field tests & & & Laborator & tests \\
\hline & Samnle collection & & Org & anic matter & & & & \\
\hline & 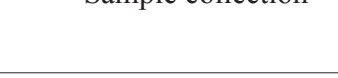 & & Content & $\begin{array}{c}\text { Degree of } \\
\text { decomposition }\end{array}$ & {$[\%]$} & $\rho s\left[\mathrm{Mg} / \mathrm{m}^{3}\right]$ & time $t[s]$ & strength $\mathrm{Rc}[\mathrm{kPa}]$ \\
\hline & $1^{\text {th }}$ dynasty & $\mathrm{W} 1 \mathrm{C}$ & mean & poorly & $1-3$ & 2.60 & 6.8 & 93.3 \\
\hline$\tilde{0}$ & $10^{\circ}$ aynasty & W1 IE & single & medium & $1-3$ & 2.64 & 12.9 & 152.7 \\
\hline 荀 & & W2 F & high & very poorly & $<1$ & 2.62 & 22.9 & 272.4 \\
\hline 里 & $20^{\text {th }}$ & W2 & high & very well & $1-3$ & 2.63 & 1595 & 170.9 \\
\hline 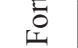 & $20^{210}$ dynasty & W3 & mean & very well & $3-5$ & 2.62 & 27.4 & 270.4 \\
\hline & & TG M & mean & medium & $>5$ & 2.63 & 23 & 376.1 \\
\hline & $18^{\text {th }}$ dynasty & $\mathrm{MH}$ & none & well & 0 & 2.61 & 9.8 & 152.6 \\
\hline 焉 & $20^{\text {th }}$ dvnasty & B 834 & mean & medium & 0 & 2.66 & 7.6 & 252.7 \\
\hline हี & 20 aynasty & H 1654 & high & poorly & $3-5$ & 2.62 & 14.5 & 202.9 \\
\hline & Third Intermediate Period & H 1607 & none & well & $>>5$ & 2.71 & 16.6 & 331.2 \\
\hline
\end{tabular}




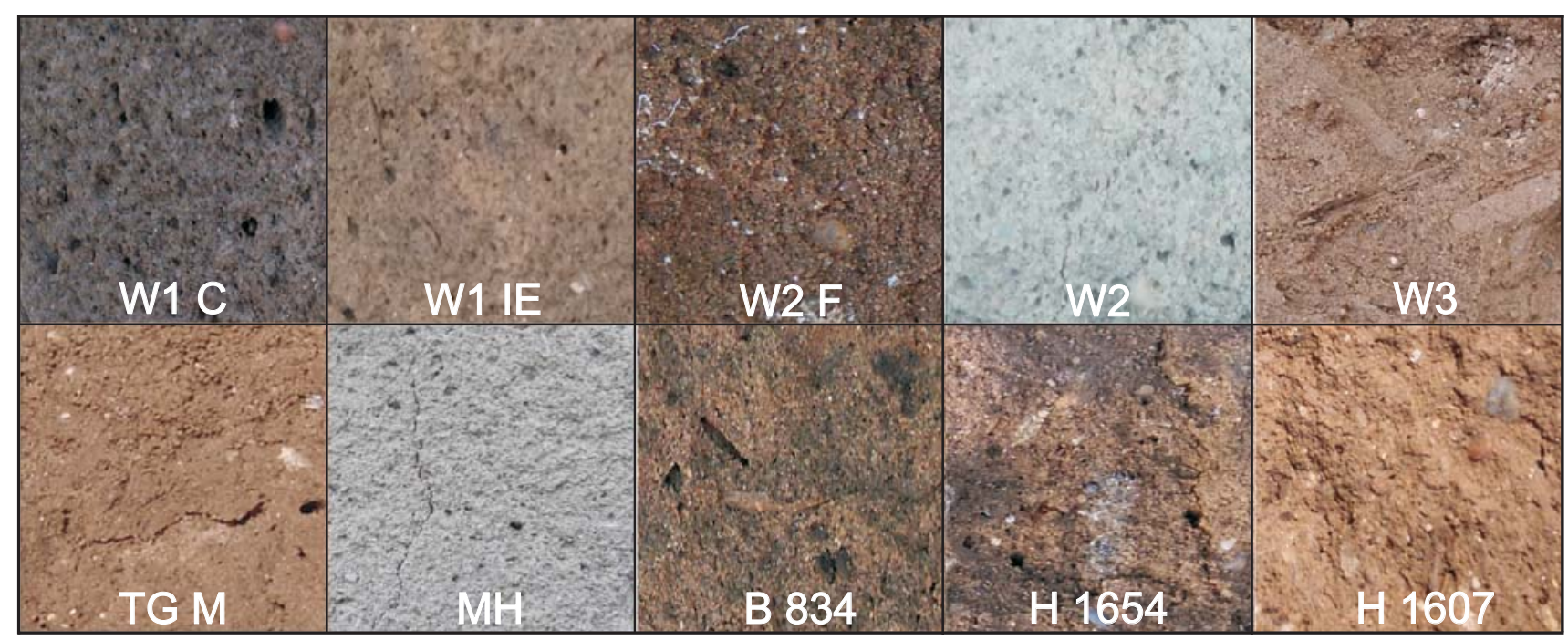

Fig. 8. Colours of bricks from fortified and domestic objects (Symbols of objects according to Table 1). Bricks colour: W1 C - very dark grey, W1 IE grey, W2 F - very dark grey, W2 - light grey, W3 - light grey, TG M - slate/dark grey, MH - light grey, B 834 - slate/dark grey, H 1654 - very dark grey, H 1607 - light grey.

ments in the Delta branches. There is no relationship in the grain size composition of the mud bricks, where a higher contribution of the clay fraction was associated with a high contribution of the silt fraction. This is because clay exploitation must have taken place in horizons corresponding to sedimentary cycles, supplying material rich in one or the other fraction. Mud bricks produced from such material for the requirements of the Tell el-Retaba fortress were thus not typical mud bricks compared to the majority of bricks produced in ancient Egypt (Trzciński et al., 2016).

The largest range of variability in the grain size composition of the mud bricks may be observed for the sand (63-88\%) and clay (3-21\%) fractions (Fig. 7). The differences for other fractions are small: from 0 to $9 \%$ for the gravel fraction and from 6 to $11 \%$ for the silt fraction. Such variability for the sand and clay fractions indicates that the manufacturers of mixtures for mud brick production used mainly the change in proportion between two materials: gezira sands and lake clays. Mud bricks with a low contribution of the gravel fraction must have been produced only from these two components.

The specific density of the mud bricks from all fortified constructions has a similar value and varies within 2.62$2.64 \mathrm{Mg} / \mathrm{m}^{3}$ (Table 1). Mud bricks from the core of "Wall 1 " (W1 C) are the only exception, for which the value of specific density is lower, at $2.60 \mathrm{Mg} / \mathrm{m}^{3}$. The discrepancies in the values of specific density result from differences in the mineral composition of the clay fraction and the organic matter content. This is indicated by the green colour of mud bricks from the internal extension of "Wall 1" (W1 IE), for which the value of this parameter is slightly higher. Mud bricks from the fortified and domestic objects are characterized by similar values of specific density $\left(2.62 \mathrm{Mg} / \mathrm{m}^{3}\right)$. Mud bricks from the core of "Wall 1" - W1 C (2.60 Mg/ $\left.\mathrm{m}^{3}\right)$ and from House $1607-\mathrm{H} 1607\left(2.71 \mathrm{Mg} / \mathrm{m}^{3}\right)$ are the only two exceptions. Similar values of specific density of mud bricks from fortified and domestic objects suggest that the material used for mud brick production had a similar mineral composition with regard to the gravel and sand fractions. Oscillations in the values of this parameter result from the amount of clay added to the bricks that is from the percentage contribution of the clay fraction in the brick material. The clays are composed mainly of clay minerals. Due to the higher values of specific density, they will increase the specific density values of mud bricks depending on the percentage contribution of the clay fraction. In turn, differences in the contribution of the gravel, sand or silt fractions did not significantly influence the values of this parameter, because their mineral composition is very similar.

Mud bricks from "Wall 2" (W2), despite the uniform grain size composition, in which the sand fraction has the largest content and the silt and clay fractions reach only $9 \%$, soak much slower than the remaining mud bricks (Table 1). The calcium carbonate content in mud bricks from this wall is not very high and reaches only $1-3 \%$. The reasons for these longer soaking times are not bonds at grain contacts, which could be formed from secondary calcite crystallization. Most probably, the added clays must have contained salts other than calcite, which must have caused secondary crystallization on grain contacts and in consequence longer soaking times. They could represent salts related to gypsum occurring in the clays, which formed strong intergranular bonds.

The addition of large amounts of clay sediments enriched in the clay fraction to the mixtures did not result in large increase of the compressive strength parameters of the bricks. Bricks from the foundation of "Wall 2" (W2 F) are a good example. The high contribution of the clay fraction should result in a much better reinforcement of the brick structure. The reasons for such situation should be sought in the composition of the added clays. The colour of these bricks is very dark and they dirty the hands when rubbed (Fig. 8). These features indicate that the bricks contain a large contribution of strongly decomposed organic matter, 
which increased the content of the clay fraction. However, during drying it did not cause cohesion between the grains as in the case of clay minerals. Therefore the increase of the compressive strength was not very high. Detailed data on the grain size composition and the physical-mechanical properties can be found in the report by Zaremba (2017).

Source of the construction material for the production of mud bricks in the New Kingdom period (1550-1069 BC)

The lake reservoir is located to the north of the Tell el-Retaba archaeological site. Clay-silt sediments, used for mud brick production, were formed here. The functioning of this reservoir was strictly related to the Nile and its periodical floods. The lake was supplied by water from Nile through the delta tributary known as Wadi Tumilat. Differences in the high or low water states caused the influx of larger or smaller quantities of water, or even its periodical lack in the reservoir. Low water in the Nile favoured the transportation of only the finest material, mainly of the clay fractions, which reached the reservoir. At that time, sediments of the clay fraction were deposited in the lake. In turn, high water of the Nile gave the opportunity of transportation also of coarse material, mainly the silt fraction. This resulted in the sedimentation of muds in the lake reservoir. Periodical low water states could also take place, during which water was not supplied to the reservoir. Lack of water could have caused drying up of the lake. Such case caused higher concentration of the solution and increase of the salt content in the water and also in the sediment. Salting out of the reservoir is observed in the drilled lake sediments with single gypsum crystals. Therefore, brackish conditions must have periodically occurred in the reservoir. An interesting issue is the presence of sulphur in the water and its origin, which caused gypsum crystallization. The only explanation of such fact was periodical connection of the lake reservoir with water flowing from the east that is from strongly salinized waters of the Red Sea and the Mediterranean Sea.

Organic matter in the clays reached the lakes through Wadi Tumilat with waters rich in these components. Particularly large amounts must have reached the reservoir during high water of the Nile. In such periods, water flowing out from the main river channel to particular delta branches transported large amounts of material in suspension. Strongly fragmented organic matter was transported over large distances not only due to particle size but also its low bulk density. This property caused that the organic particles, being lighter than mineral matter, were not deposited and could be transported for a long time in the suspension.

Another source of organic matter, which occurs in the mud bricks, could be shallow backwaters around the lake. Such backwaters were documented during geological fieldwork around the Tell el-Retaba site (Rzepka et al., 2015). Frequent water level oscillations in the lake caused on the one hand flooding of low ground around the lake and on the other hand - drying up of the flooded areas. Such situation favoured intense vegetation in these areas, due to which local accumulation of organic matter must have taken place. Such deposits were drilled round the fortress, and the degree of decomposition of organic remains was variable (Fig. 6B). Such deposits were also the source of organic matter, which was found in the bricks produced for the construction of the foundation of "Wall 2".

\section{PALAEOENVIRONMENTAL RECONSTRUCTION OF THE OPEN-PIT MINE AT TELL EL RETABA}

Analysis of drilling data and the resulting geological cross-section (Fig. 5A) have allowed for the reconstruction of the northern part of the site during the Ramesses II and Ramesses III times (1186-1155 BC) (Fig. 5B). Geomorphology and ancient environmental conditions that could have taken place prior to settlement were also reconstructed (Fig. 5C).

The area around the fortress was subject to intense anthropopression. The presently observed top of the clays and the gezira sands is not a primary surface. These surfaces have significantly changed due to human activity in this area in ancient times. The top of gezira sands falling towards the south must have been much higher due to the much higher position of the clay sediments to the north. Moreover, analysis of the area to the west of the fortress has indicated that the area with the fortified objects was the highest ground. In turn, the top of lake sediments must have been horizontal, and in result their range must have been much larger to the south (Fig. 5C). At present, both the top of the gezira sands and the top of the clays slopes to the south. Such structure of the layers suggests only one possible solution. The constructors of the fortress required large amounts of material for mud brick production. Local sediments occurring around the planned fortress became perfect material for this achievement. To the north occurred lake clays and coarser grained gezira sands with variable grain size composition, and local gravels which covered the highest sand occurrences. These materials occurred close to the planned fortress and did not require long transportation to the mud brick production site and to the construction site. Clays, sands and gravels were systematically exploited, depending on the requirements and proceeding fortress construction, resulting in the formation of an open-pit mine (Fig. 5B). With proceeding exploitation, the bricks were produced in the open-pit mine, and the readymade construction material was transported to the fortress construction site. As a result, the clay top attained a terrace structure and the initial elevation formed by gezira sands became a depression. Large amounts of water were also required for brick production. It is estimated that water must have contributed to about $30 \%$ of the volume in relation to the remaining material (Zaremba, 2017). This is a considerable amount, taking into account that the capacity of all walls, the entrance gate and the foundation under "Wall 2" was enormous and must have reached even $175,000 \mathrm{~m}^{3}$. Such capacity required the use of around 300,000 tons of sandclay sediments and 90,000 tons of water, which corresponds to the volume of almost 30 Olympic stadiums. Such amounts of material indicate that both the source of water and the open-pit mine must have been located close to the destina- 


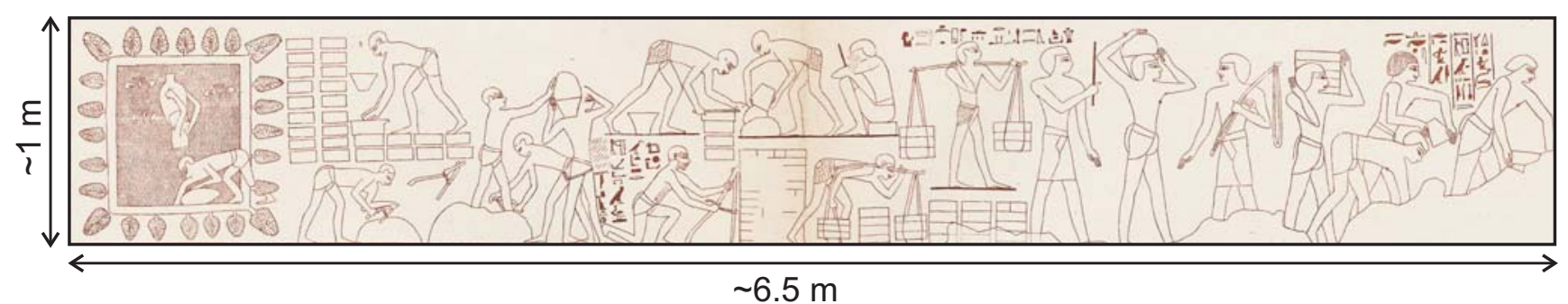

Fig. 9. Relief showing the process of mud brick production (Newberry 1900)

tion construction site. It may be assumed that there were numerous surface water reservoirs as remains after larger basins, in which lake sediments next used for brick production were deposited (Fig. 5C).

\section{CONCLUSIONS}

Mud bricks as construction material were not suitable for long transportation. Their low mechanical strength and poor cohesiveness could have caused large loss during shocks developed in transportation from the production site to the construction site. Therefore, the location of planned constructions had to ensure manual transportation of bricks. Also, the brick production site, requiring access to several components, must have been located to ensure an easy and fast transportation. Reliefs presenting activities during the production of mud bricks reveal the close vicinity of a water reservoir, from which mixtures with a relevant consistence were supplied (Fig. 9). Next, the mixtures were mixed in relevant proportions and bricks were formed, which after drying were transported to the construction site.

When selecting a place for fortress localization, its constructors were mainly guided by the availability of gravel, sand and clay, and also water as components for brick production, which is the most common construction material in ancient Egypt. This place was chosen due to their close availability and the neighbourhood of small elevations, on which the fortress walls were founded.

\section{Acknowledgements}

The research was supported by the Polish National Science Centre (Grant no. 2012/05/B/HS3/03748) and the Slovak Research and Development Agency (Grant APVV-5970/12). Gratitude is expressed to two anonymous referees, whose remarks significantly improved the final version of the paper.

\section{REFERENCES}

Butzer, K.W., 1976. Early Hydraulic Civilization in Egypt: A Study in Cultural Ecology. The University of Chicago Press.

Emery, V.L., 2011. Mud-Brick Architecture. In: Wendrich, W., (Ed.), UCLA Encyclopedia of Egyptology, Los Angeles.

Górka, K., Rzepka, S., 2011. Infant burials or infant sacrifices? New Discoveries from Tell el-Retaba. Mitteilungen des Deutschen Archäologischen Instituts Kairo 67, 93-100.
Kemp, B., 2009. Soil (including mud - brick architecture). In: Nicholson, P.T., Shaw, I. (Eds) Ancient Egyptian Materials and technology. Cambridge, 78-103.

Newberry, P.E., 1900. The Life of Rekhmara Vezir of Upper Egypt under Thothmes III and Amenhetep II: (circa B.C. 1471-1448) with Twenty-two plates. Westminster Archibald Constable and Co. Ltd, Whitehall Gardens.

Petrie, W.M.F., Duncan, J.G., 1906. Hyksos and Israelite Cities. British School of Archaeology in Egypt 12, London.

PKN-CEN ISO/TS 17892-7 2009. Badania geotechniczne. Badania laboratoryjne gruntów. Część 7: Badanie na ściskanie gruntów drobnoziarnistych $\mathrm{w}$ jednoosiowym stanie naprężenia. Polski Komitet Normalizacyjny.

Polska norma (PN-88/B-04481), 1988. Grunty budowlane. Badania próbek gruntu. Polski Komitet Normalizacyjny.

Redmount, C.A., 1989. On an Egyptian/Asiatic Frontier: An Archaeological History of the Wadi Tumilat. PhD Thesis, The University of Chicago.

Rzepka, S., Wodzińska, A., Hudec, J., Herbich, T., 2009. Tell el-Retaba 2007-2008. Ägypten\&Levante 19, 241-280.

Rzepka, S., Wodzińska, A., Malleson, C., Hudec, J., Jarmużek, Ł., Misiewicz, K., Małkowski, W., Bogacki, M., 2011. New Kingdom and the Third Intermediate Period in Tell el-Retaba. Results of the Polish-Slovak Archaeological Mission, Seasons 2009-2010. Ägypten\&Levante 21, 139-184.

Rzepka, S., Nour el-Din, M., Wodzińska, A., Jarmużek, Ł. 2012/2013. Egyptian Mission Rescue Excavations in Tell el-Retaba. Part 1: New Kingdom Remains. Ägypten\&Levante 22/23, 253-288.

Rzepka, S., Hudec, J., Wodzińska, A., Jarmużek, Ł., Hulková, L., Dubcová, V., Piorun, M., Šefčáková, A., 2014. Tell el-Retaba from the Second Intermediate Period till the Late Period. Results of the Polish-Slovak Archaeological Mission, seasons 2011-2012. Ägypten\&Levante 24, 41-122.

Rzepka, S., Hudec, J., Jarmużek, Ł., Dubcová, V., Hulková, L., Odler, M., Wodzińska, A., Trzciński, J., Šefčáková, A., Sójka, P., Fulajtar, E., Černý, M., Tirpák, J., 2015. From Hyksos settlers to Ottoman pipe smokers. Tell el-Retaba 2014. Ägypten\&Levante 25 (in print). Spencer, A.J., 1979. Brick architecture in Ancient Egypt. Aris \& Phillips.

Stanley, J., Warne, A.G., 1993. Nile Delta: Recent Geological Evolution and Human Impact. Science 260, 628-634.

Trzciński, J., Zaremba, M., Rzepka, S., Welc, F., Szczepański, T., 2016. Preliminary report on engineering properties and environmental resistance of the ancient mud bricks from Tell el-Retaba archaeological site in the Nile delta. Studia Quatenaria 33 (1), 47-56.

Welc, F., 2016. Holocene climate change in the lower Nile Basin based on geoarchaeological data from the Faiyum Oasis, Egipt. SNAP Warsaw.

Welc, F., Marks, L., 2014. Climate change at the end of the Old Kingdom in Egypt around 4200 BP: new geoarchaeological evidence. Quaternary International 324, 124-133.

Zaremba, M., 2017. The strength of mud bricks used in ancient Egypt in residential and defensive buildings on the example of Tell el-Retaba site. Master thesis. 